\title{
Tar, nicotine, and carbon monoxide yields of some Nigerian cigarettes
}

\author{
A A A WOTED_, ${ }^{1} \mathrm{~T}$ W HIGENBOTTAM, ${ }^{2}$ AND B O ONADEKO ${ }^{1}$
}

From the Department of Medicine, ${ }^{1}$ University College Hospital, Ibadan, Nigeria, and the Respiratory Physiology Department, ${ }^{2}$ Papworth Hospital, Papworth Everard, Cambridge CB3 8RE, UK

SUMMARY Fourteen cigarette brands manufactured in Nigeria in 1981 were analysed to determine the tar, nicotine, and carbon monoxide yields. Five of the brands belonged to the high and middle to high tar category ( $>22 \mathrm{mg} /$ cigarette) and nine to the middle tar (17-22 mg/cigarette) category. None of the cigarettes was in the low to middle and low $\operatorname{tar}(<17 \mathrm{mg} /$ cigarette $)$ category. The nicotine and carbon monoxide yields were similar to those of European cigarettes. Tobacco companies need to manufacture low tar cigarettes in the third world as is the practice in the economically developed parts of the world.

Over the past three decades researchers have drawn attention to the various health problems caused by cigarette smoking. Overwhelming evidences incriminated smoking to varying extents in the pathogenesis of chronic obstructive bronchitis and coronary heart disease, as well as carcinoma of the bronchus, larynx, oesophagus, and bladder. ${ }^{1-3}$ Attention has also been focused on the constituents of cigarettes smoke implicated in the pathogenesis of these different diseases. The well recognised are tar, nicotine, and carbon monoxide, while others of lesser importance include nitrogen oxides, cyanide, and acrolein. ${ }^{4}$ Tar and nicotine are the major constituents of cigarette smoke implicated as causative factors for coronary heart disease and carcinoma of the bronchus. $^{5-8}$

In recognition of these facts various governments have entered agreements with tobacco companies to lower the tar and nicotine yields of their products. Smoking was introduced to Africa sometime in the fourteenth century and since then the habit has been on the increase. ${ }^{\circ}$ Earlier beliefs that the diseases related to smoking were not found in the African have changed with the findings from recent studies from parts of Africa. ${ }^{10-12}$ Not only are these diseases present, but in some cases the incidence is increasing. ${ }^{13}$ There is also a suspicion that the tobacco companies because of the anti-tobacco lobby in Europe and America are diverting their attention to the third world, where the promotion of cigarette smoking is unrestricted.

There are no data on the tar, nicotine, and carbon monoxide yields of cigarette manufactured in Nigeria and most African countries. The present study reports the analysis of smoke constituents of cigarettes available in Nigeria.

\section{Material and methods}

Ten packets of each of the 14 commonly available cigarette brands in Nigeria were purchased from different shopping centres in the town. All the cigarettes had been recently manufactured. The cigarettes were smoked in a Filtrona smoking machine and later analysed for tar, nicotine, and carbon monoxide yields using the method agreed by the laboratory of the government chemist and the tobacco companies. ${ }^{17}{ }^{15}$ The tar yield was classified as:

High and (middle to high)_Values greater than $22 \mathrm{mg} /$ cigarette.

Middle-Value 17-22 mg/cigarette.

(Low to middle) and low-Less than $17 \mathrm{mg} /$ cigarette.

The costs of the different cigarette brands as sold in the local shops were noted. A structured questionnaire was administered to 1000 people specifically asking which of the cigarette brands they smoked and their cash earning power. The subjects were randomly selected. 
The socioeconomic groups were classified as:

\section{High income-}

Annual income was about 10000 and above.

\section{Middle income-}

Annual income $3000-10000$, and

Low income-Annual income below 3000 .

\section{Results}

Table 1 shows the tar, nicotine, and carbon monoxide yields of the different cigarette brands analysed. Also included in this table is the percentage of the smokers interviewed smoking each brand of cigarette.

Table 1 Tar, nicotine, and carbon monoxide yields of some Nigerian cigarettes

\begin{tabular}{|c|c|c|c|c|}
\hline Cigarette brands & $\begin{array}{l}\text { Tar } \\
(\mathbf{m g})\end{array}$ & $\begin{array}{l}\text { Nicotine } \\
\text { (mg) }\end{array}$ & $\begin{array}{l}\text { Carbon } \\
\text { monoxide } \\
\text { (mg) }\end{array}$ & $\begin{array}{l}\text { \%of people } \\
\text { smoking } \\
\text { each brand }\end{array}$ \\
\hline \multicolumn{5}{|c|}{ A Benson and Hedges } \\
\hline \multirow{2}{*}{\multicolumn{2}{|c|}{ B Benson and Hedges }} & $1 \cdot 5$ & $17 \cdot 1$ & \\
\hline & 20 & 1.6 & 15.6 & \\
\hline \multicolumn{5}{|c|}{ C State Express 555} \\
\hline \multicolumn{5}{|c|}{$\begin{array}{l}\text { filter king } \\
\text { D State Express 555 }\end{array}$} \\
\hline \multicolumn{5}{|c|}{ International 21} \\
\hline \multicolumn{2}{|l|}{$\begin{array}{l}\text { F Varsity } \\
\text { Menthol }\end{array}$} & $1 \cdot 1$ & $15 \cdot 8$ & $3 \cdot 0$ \\
\hline & 0.6 \\
\hline & $\begin{array}{l}3.2 \\
24\end{array}$ & $\begin{array}{l}1.5 \\
1.5\end{array}$ & $\begin{array}{l}16 \cdot 6 \\
18 \cdot 8\end{array}$ & $\begin{array}{l}0.6 \\
0.3\end{array}$ \\
\hline \multirow{3}{*}{$\begin{array}{l}\text { J } 3 \text { Ring } \\
\text { K Sweet Menthol } \\
\text { filter } \\
\text { L Sweet Menthol } \\
\text { king size filter } \\
\text { M Mars filter } \\
\text { N Bicycle }\end{array}$} & $\begin{array}{l}27 \\
19\end{array}$ & $\begin{array}{l}1 \cdot 7 \\
1 \cdot 2\end{array}$ & $\begin{array}{l}20 \cdot 0 \\
16 \cdot 3\end{array}$ & $\begin{array}{r}23.9 \\
0.3\end{array}$ \\
\hline & 20 & $1 \cdot 2$ & $17 \cdot 3$ & $32 \cdot 8$ \\
\hline & $\begin{array}{l}21 \\
20 \\
27\end{array}$ & $\begin{array}{l}1.6 \\
1.6 \\
1.7\end{array}$ & $\begin{array}{l}16.8 \\
17.0 \\
20.0\end{array}$ & $\begin{array}{l}0 \cdot 6 \\
2 \cdot 2\end{array}$ \\
\hline \multicolumn{5}{|l|}{$\begin{array}{l}2.0 \% \text { belong } \\
\text { to other } \\
\text { cigarette } \\
\text { brands not }\end{array}$} \\
\hline
\end{tabular}

None of the cigarettes analysed was in the low tar category (table 2), five were in the high to middle and high group, and the remaining nine were in the middle tar category. Four brands in the high tar category were smoked by those in the middle socioeconomic group (table 3). The five high tar cigarette brands when polled together were consumed by $27.6 \%$ of the people interviewed.

Table 2 Tar yield analysis of Nigerian cigarettes

\begin{tabular}{lll}
\hline & Tar (mg/cigarette) & No of cigarette brands \\
\hline $\begin{array}{l}\text { High and middle } \\
\text { to high }\end{array}$ & $>22 \mathrm{mg}$ & 5 \\
$\begin{array}{l}\text { Middle } \\
\text { Low to middle } \\
\text { and low }\end{array}$ & $17-22 \mathrm{mg}$ & 9 \\
\hline
\end{tabular}

Table 3 Socioeconomic groups and most of each brand of cigarette related to the tar yield

\begin{tabular}{llc}
\hline Cigarette & $\begin{array}{l}\text { Average cost of } \\
\text { cigarette per } \\
\text { packet of } 20\end{array}$ \\
lncome grouping & A, B, C, D & N1.00 \\
High income & E, F, G, H, I & 55 kobo \\
Middle income & J, K, L, M, N & 35 kobo \\
Low income & & \\
\hline
\end{tabular}

None of the cigarettes belong to the low nicotine $(<1 \mathrm{mg}$ ) category, although in four brands the levels were reasonably low $(1.1-1.3 \mathrm{mg})$. The carbon monoxide levels are within the range of European and American cigarettes.

\section{Discussion}

Both governments and various antismoking organisations have made concerted efforts to persuade tobacco companies to produce low tar and low nicotine cigarettes. Such measures have led to reductions of $49 \%, 31 \%$, and $11 \%$ in the tar, nicotine, and carbon monoxide yields respectively of cigarettes manufactured between 1934 and 1979 in Great Britain/United Kingdom. ${ }^{16}$

The only available data on the yields from cigarettes manufactured in Africa showed a disparity in tar yields between similar brands of cigarettes sold in Nairobi, Kenya, and the United Kingdom as shown by the findings that the State Express 555 sold in Kenya contained $31 \mathrm{mg}$ tar and $2 \mathrm{mg}$ nicotine but the same brand in the United Kingdom had $18 \mathrm{mg}$ tar and $0.9 \mathrm{mg}$ nicotine. ${ }^{17}$

Our study showed that five brands belonged to the high tar category and would have attracted tax surcharge if sold in the UK. ${ }^{18}$ It is remarkable that none of the cigarettes belonged to the low tar category, which is the trend among tobacco companies in Europe and America. It is also interesting that the cigarettes consumed by those in low and middle income groups belong predominantly to the high tar category and are relatively cheap. The implications of this are that although these people may smoke fewer cigarettes, in terms of total tar consumption they may be at the same risk of developing lung cancer as someone who smokes more low tar cigarettes. It is difficult for any government to ban smoking because of economic considerations and the only alternative would be production of safer cigarettes.

Lowering the tar and nicotine yields of cigarettes has been reported to cause some decrease in the incidence of some smoking related diseases. ${ }^{19-22}$ In view of the above observations tobacco companies need to conform to international standards in terms of yields from cigarettes sold in Africa. The various 
governments must enact legislation to regulate cigarette promotions and for the cigarette packets to carry health warnings as well as imprints of tar, nicotine, and carbon monoxide yields as practised in Europe and America.

Unfortunately a recent attempt in Nigeria to enact such legislation was rejected because of lack of data. Perhaps with this information the issue may be more favourably considered in future. If action is not taken now we may be supplanting the various infective disorders related to poverty with tobacco related diseases, a problem that has been referred to as "the coming epidemic. ${ }^{22}$

We acknowledge the expertise of Graham Copeland of the laboratory of government chemist, United Kingdom for his analysis of the various cigarettes.

This study was partly funded by the University of Ibadan Senate Research Grant 2/SRG3/107.

\section{References}

${ }^{1}$ Doll R, Hill AB. A study of the aetiology of carcinoma of the lung. Br Med J 1952; ii: 1271-86.

${ }^{2}$ Doll R, Hill AB. Mortality in relation to smoking. 10 years observation of British doctors. Br Med J 1964; i: 1399 1460.

${ }^{3}$ Doll R, Gray R, Haffner B, Peto R. Mortality in relation to smoking. 22 years observations on female British doctors. Br Med J 1980; 280: 967-71.

${ }^{4} \mathrm{Gori}$ GB, Lynch CJ. Towards less hazardous cigarettes. Current advances. JAMA 1978; 240: 1255-9.

${ }^{5}$ Frautnani JP. Cigarette smoking and cancer of the urinary tract. Geographic variations in the United States. J Natl Cancer Inst 1968; 41: 1205-11.

${ }^{6}$ Auerbach O, Stout AP, Hammond ED, et al. Histologic changes in oesophagus in relation to smoking habit. Arch Environ Health 1969; 11: 4-15.
${ }^{7}$ Anderson EW, Andelman EJ, Strauch JM, et al. Effect of low level carbon monoxide exposure on onset and duration of angina pectoris. A study of ten patients with ischaemic heart diseases. Ann Intern Med 1973; 79: 46-50.

${ }^{8}$ Arnow WS. Smoking, carbon monoxide and coronary heart disease. Circulation 1973; 48: 1169-72.

${ }^{\circ}$ Femi-Pearse D, Adeniyi A, Oke AB. Respiratory symptoms and their relationship to cigarette smoking, dusty occupations and domestic air pollution studies in random sample of an urban African population. West Afr Med J 1973; 22: 57-63.

${ }^{10}$ Schonland M, Bradshaw E. Smoking pattern in South Africans and Indians of Natal. Int J Cancer 1969; 4: 743-51.

${ }^{11}$ Grillo AI, Sofowara EO. Primary tumours of the lung and pleura in Nigerians. J Nat Med Assn 1971; 63: 166-72.

${ }^{12}$ Cookson JB, Mataka G. Prevalence of chronic bronchitis in Rhodesian Africans. Thorax 1978; 33: 328-34.

${ }^{13}$ Taha A, Ball K. Smoking and Africa: the coming epidemic. $\mathrm{Br}$ Med J 1980; 280; 991-3.

${ }^{14}$ Copeland GKE, Stockwell PB. Automatic large-scale routine analysis of cigarette smoke. In: Foreman JK, Stockwell PB, eds. Topics in automatic chemical analysis. Chichester: Ellis Harwood, 1979.

${ }^{15}$ International Organisation for Standardisation. International standard 150. Geneva: IOS, 1978: 3402.

${ }^{16}$ Wald N, Doll R, Copeland G. Trends in tar, nicotine, and carbon monoxide yields of UK cigarettes manufactured since 1934. Br Med J 1981; 282: 763-5.

${ }^{17}$ Wickstrom BO. Cigarette marketing and the third world. Gothenburg, Sweden: University of Gothenburg, 1979.

${ }^{18}$ Russel MAH, Jarvis M, Iyer R, Feyersband C. Relation of nicotine yield of cigarette to blood nicotine concentrations in smokers. $\mathrm{Br} \mathrm{Med} J \mathrm{~J}$ 1980; 280: 972-6.

${ }^{19}$ Gori GB. Low-risk cigarettes: a prescription. Science 1976; 194: 1243-6.

${ }^{20}$ World Health Organisation. Controlling the smoking epidemic. Geneva: WHO, 1979. (WHO Tech Rep Ser No 636.)

${ }^{21}$ Wynder EL, Hoffman D. Tobacco and health: a societal challenge. N Engl J Med 1979; 300: 894-903.

${ }^{22}$ US Surgeon General Report. Smoking and Health. Washington DC: United States Government Printing Office, 1979. 